\title{
NSAID antinociception measured in a chemical and a thermal assay in mice
}

\author{
HF Miranda PhD, J Lopez MA, F Sierralta DDS, A Correa MA, G Pinardi MD
}

HF Miranda, J Lopez, F Sierralta, A Correa, G Pinardi.

NSAID antinociception measured in a chemical and a thermal assay in mice.

Pain Res Manage 2001;6(4):190-196.

The antinociceptive activity of several nonsteroidal anti-inflammatory drugs (NSAIDs) that were administered either intraperitoneally or intrathecally was assessed in mice by two algesiometric tests. The first was the writhing test, which assessed the abdominal constrictions that were induced by intraperitoneal acetic acid (a chemical test), and the second was the tail flick test, which measured pain responses to heat stimuli. The corresponding effective doses and their relative potencies were compared because these tests use different nociceptive stimuli with different transmission pathways. The intraperitoneal and intrathecal dose-response curves for the antinociception induced by every NSAID that was tested were parallel in the writhing test. In the tail flick test, however, only the intraperitoneal and intrathecal dose-response curves for ketoprofen, piroxicam, naproxen, nimesulide, paracetamol and diclofenac were parallel. The results obtained in this study confirm that NSAIDs possess different abilities to induce inhibition of cyclooxygenase, and they can be indirectly assessed by their different antinociceptive activities, depending on the algesiometric assays that are used. The antinociception of most NSAIDs might involve central mechanisms. The findings demonstrate the increasing importance of the spinal cord in processing and modulating nociceptive input, because intrathecal administration of NSAIDs is always more effective (in terms of potency) than systemic administration; thus, the antinociceptive efficacy of NSAIDs strongly depends on the algesiometric assay that is used and on the type of the nociceptive stimulus to which the test subject is exposed.

Key Words: Antinociception; Nonsteroidal anti-inflammatory drugs; Tail flick test; Writhing test

\section{L'antinociception amenée par les AINS telle que mesurée dans des tests chimique et ther- mique chez la souris}

RÉSUMÉ : L'activité antinociceptive de plusieurs anti-inflammatoires non stéroïdiens (AINS) qui ont été administrés soit par voie intrapéritonéale, soit par voie intrathécale a été évaluée chez des souris au moyen de deux tests algésiométrique. Le premier a été le test de torsion qui visait à évaluer les contractions abdominales induites par l'acide acétique intrapéritonéal (test chimique) et le second était le test du battement de la queue qui mesurait les réponses douloureuses aux stimuli thermiques (test thermique). Les doses efficaces correspondantes et leur puissance relative ont été comparées, parce que ces tests utilisent des stimuli nociceptifs différents dont les voies de transmission sont également différentes. Les courbes dose-réponse intra-péritonéales et intrathécales pour l'antinociception induite par chaque AINS testé ont été parallèles dans les tests de torsion. Dans les tests de battement de la queue, par contre, seules les courbes dose-réponse intra-péritonéales et intrathécales du kétotifène, du piroxicam, du naproxène, du nimésulide, du paracétamol et du diclofénac ont été parallèles. Les résultats obtenus lors de cette étude confirment que les AINS induisent, à divers degrés, l'inhibition de la cyclo-oxygénase et qu'ils peuvent indirectement être évalués par leurs activités antinociceptives distinctes selon les tests algésiométriques utilisés. L'antinociception de la plupart des AINS pourrait mettre en jeu des mécanismes centraux. Les conclusions confirment l'importance croissante de la moelle épinière dans le processus et la modulation de l'influx nociceptif, parce que l'administration intrathécale des AINS est toujours plus efficace (sur le plan de la puissance) que l'administration systémique. Ainsi, l'efficacité antinociceptive des AINS dépend fortement du test algésiométrique utilisé et du type de stimulus nociceptif auquel le sujet est exposé.

Pharmacology Program, ICBM, Faculty of Medicine, Universidad de Chile, Santiago, Chile

Correspondence: Dr HF Miranda, Faculty of Medicine, Universidad de Chile, Box 70.000, Santiago 7, Chile. Telephone +56-2-678-6052,

fax +56-2-737-2783, e-mail hmiranda@machi.med.uchile.cl

Received for publication August 30, 2000. Accepted August 29, 2001 
$\mathrm{N}^{\mathrm{s}}$ onsteroidal anti-inflammatory drugs (NSAIDs) are a group of agents that possess both analgesic and antiinflammatory properties. They are used in the treatment of a variety of pain and inflammatory disorders. There is substantial evidence that NSAID-induced analgesia is due to the inhibition of prostaglandin synthesis in both the peripheral and central nervous systems (1). Prostaglandins are generated through two isoforms of the enzyme cyclooxygenase $(\mathrm{COX})$ : the constitutive isoform (COX-1) and the isoform that is induced at sites of inflammation (COX-2). Most NSAIDs are principally inhibitors of COX-1, while others (eg, meloxicam, nimesulide, celecoxib and rofecoxib) have pharmacological profiles that are clearly different and are characterized by a more selective inhibition of COX-2 (2). Meloxicam, compared with other NSAIDs, is the most potent inhibitor of prostaglandin biosynthesis in pleural and peritoneal exudates, but is only a weak inhibitor in the gastric tract and kidney. Unlike other NSAIDs, meloxicam preferentially inhibits inducible human COX-2 in COS cells $(3,4)$. The activity of nimesulide against COX-1 and COX-2, measured in vitro and in vivo, demonstrated that it is a selective inhibitor of COX-2 (5). Several additional substances have been reported to be potentially involved in the modulation of the antinociceptive activity of NSAIDs. These include substance $\mathrm{P}$, nitric oxide, adenosine triphosphate, glutamate, serotonin, neurokinin, noradrenaline, ion channels and acetylcholine (6-13).

Previous studies have demonstrated that NSAIDs can induce antinociception in several algesiometric tests; however, a detailed comparative study of the dose-response characteristics of several NSAIDs in two different algesiometric tests has not been performed. The writhing test (visceral pain) and the tail flick test (somatic pain) are animal models of acute pain in which the nociceptive stimulus and the transmission pathways are different (14). The purpose of the present study was to examine the antinociceptive effect of NSAIDs that were administered intraperitoneally and intrathecally in these chemical and thermal algesiometric assays, to determine their corresponding effective doses and to discuss their relative potencies.

\section{ANIMALS AND METHODS}

CF-1 mice that weighed $25 \pm 3 \mathrm{~g}$ were used throughout the study. The animals were acclimated to the laboratory environment for a minimum of $2 \mathrm{~h}$ before being used, and the ethical standard guidelines were followed (14). In particular, the durations of the experiments were as short as possible, the number of animals involved was kept to a minimum, and the animals were killed by the administration of an anesthetic overdose immediately after the recording period. Each animal was used only once and received only one dose of the drugs that were tested. All drugs were freshly prepared by dissolving them in normal saline or in a slightly hyperbaric solution of glucose $(6 \%)$, and doses were calculated on the basis of the drug salts. All observations during the assay were made in a randomized and blind manner. Antinociceptive activity was evaluated as previously reported (15). Briefly, intraperitoneal administration was accomplished $30 \mathrm{~min}$ before the algesiometric test by injecting the total dose in a constant volume of $10 \mathrm{~mL} / \mathrm{kg}$. The Hylden and Wilcox (16) technique was used for intrathecal administration $15 \mathrm{~min}$ before the algesiometric test, and the doses of the drugs (dissolved in a slightly hyperbaric solution of glucose $[6 \%$ ] to limit diffusion) were injected in a constant volume of $5 \mu \mathrm{L} / \mathrm{g}$. The procedure was performed rapidly, with a high degree of accuracy and reproducibility. These times (30 min for intraperitoneal administration and $15 \mathrm{~min}$ for intrathecal administration) were found in previous experiments to be near the time of the onset of maximum analgesic effect.

\section{Algesiometric tests}

Writhing test: Mice were injected intraperitoneally with $10 \mathrm{~mL} / \mathrm{kg}$ of $0.6 \%$ acetic acid, and starting $5 \mathrm{~min}$ after the administration of the acetic acid solution, the number of writhes during a 5 min period was counted. A writhe was defined as a contraction of the abdominal muscles, accompanied by an elongation of the body and an extension of the hind limbs. Dose-response curves, which were determined near the time of peak effect, were constructed to assess the antinociceptive actions of the different NSAIDs that were administered either intraperitoneally or intrathecally. Eight animals were injected at each of four doses to determine a dose-response curve. The dose that produced $50 \%$ of antinociception $\left(\mathrm{AD}_{50}: 50 \%\right.$ reduction of control writhes) was calculated by a standard linear regression analysis of the dose-response curve. Antinociceptive activity was expressed as a percentage of inhibition of the usual number of writhes that were observed in control animals that received intraperitoneal saline $(24.3 \pm 1.0, n=42)$ or intrathecal glucose $(23.9 \pm 0.5, \mathrm{n}=42)$.

Tail flick test: A radiant heat tail flick test algesiometer unit was used to measure response latencies according to the method that was described by D'Amour and Smith (17). Animals responded to a focused heat stimulus by flicking or removing their inflicted tails from the heat source. The intensity of the light beam was adjusted so that the control latency (baseline) readings were approximately $2.5 \mathrm{~s}$, and an $8 \mathrm{~s}$ cutoff time was used to prevent tissue damage. Antinociception activity was expressed according to the following formula:

$$
\begin{gathered}
\% \text { antinociception }=100 \times[(\text { test latency-control } \\
\text { latency) } /(\text { cutoff time-control latency })]
\end{gathered}
$$

A dose-response curve was determined by using at least four doses of each NSAID, and the $\mathrm{AD}_{50}$ was determined by linear regression analysis.

All of the drugs used in the study were dissolved in saline solution when they were administered intraperitoneally or, in the case of intrathecal administration, in a slightly hyperbaric solution of glucose $(6 \%)$ to limit diffusion (with the exception of ibuprofen and nimesulide, which were dissolved in $5 \mathrm{~mm}$ dimethylsulphoxide; this vehicle was 


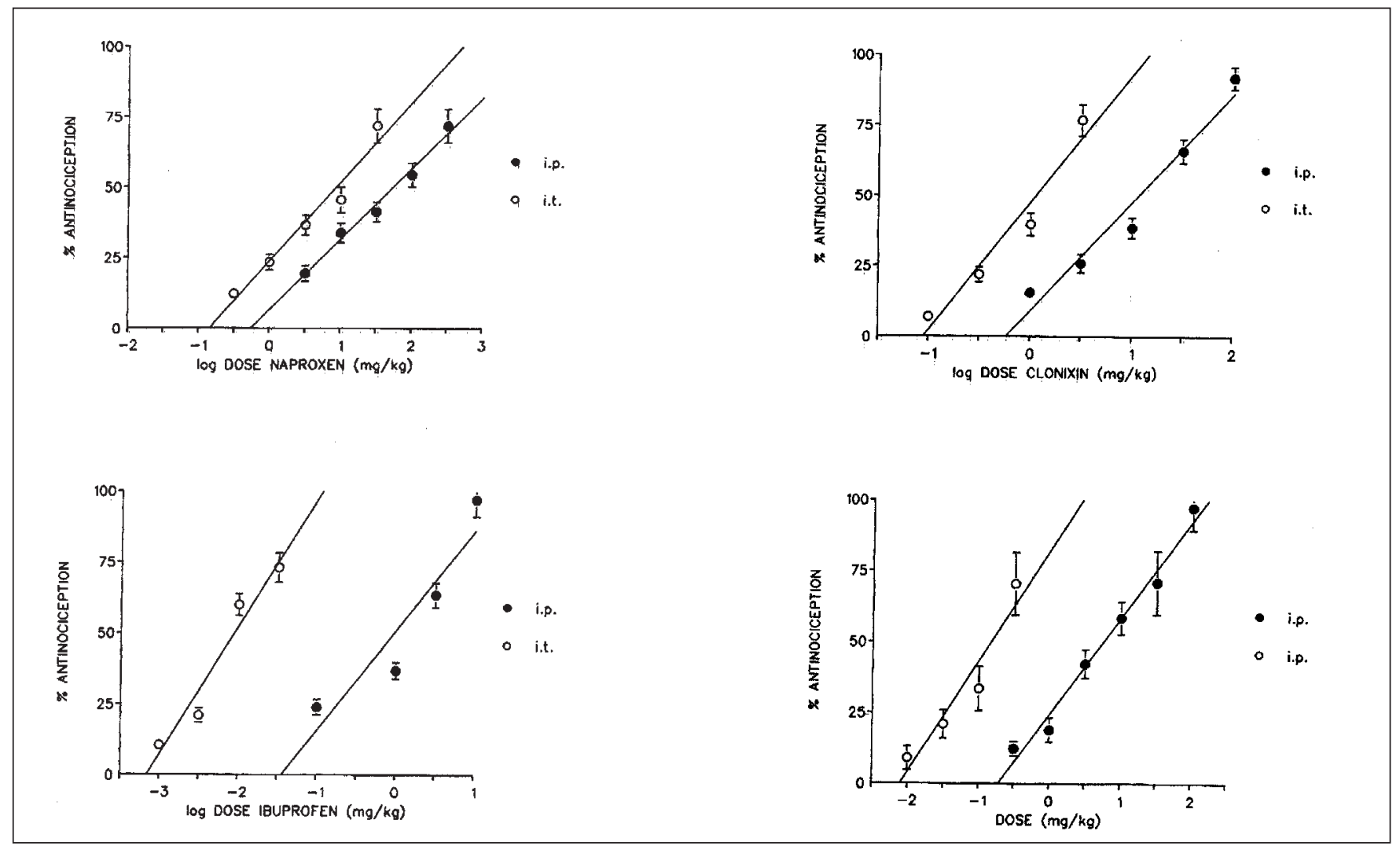

Figure 1) Dose-response curves of the antinociceptive activity of naproxen, clonixin, ibuprofen and diclofenac administered intraperitoneally (i.p.) and intrathecally (i.t.) in the writhing test in mice

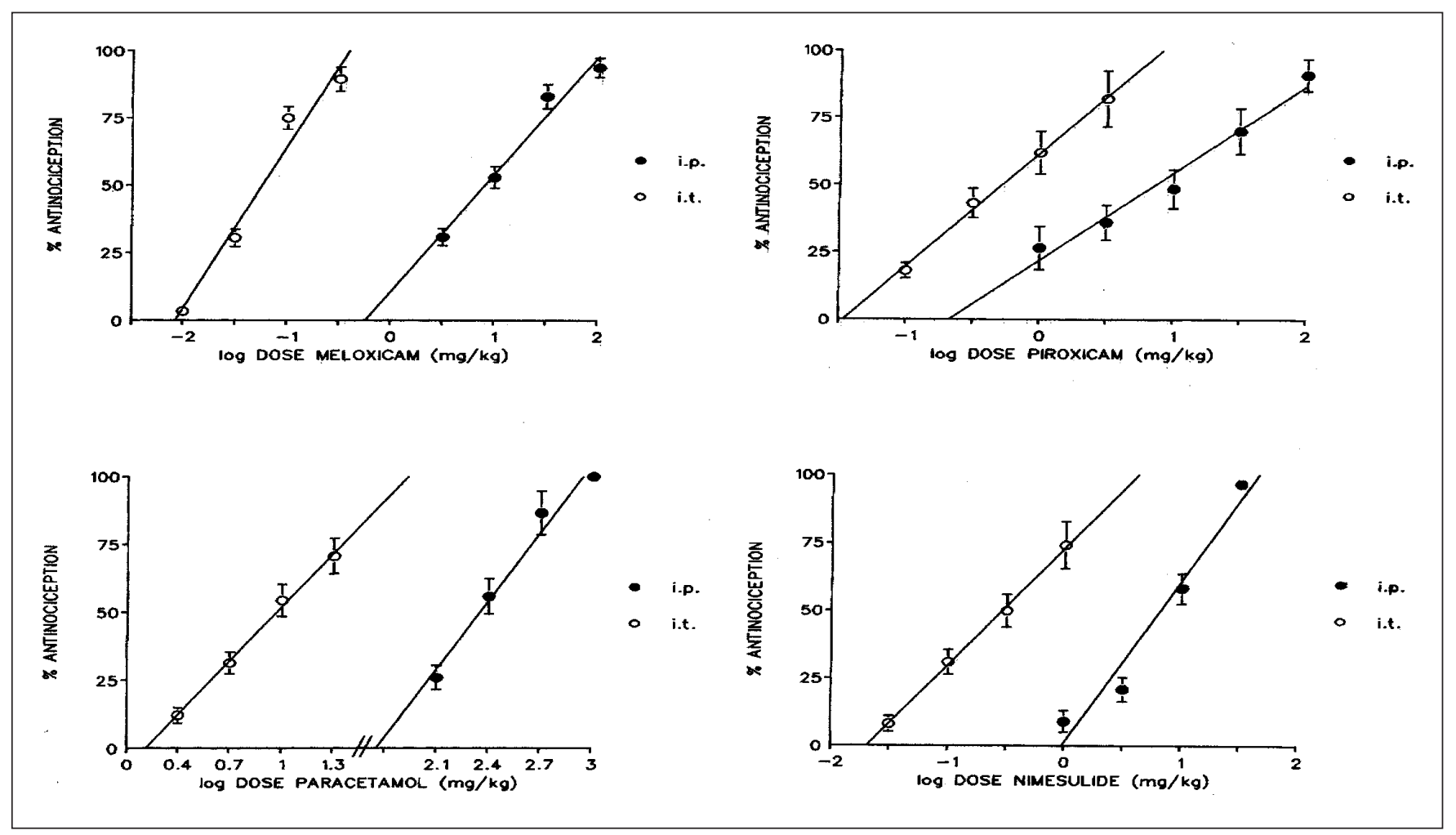

Figure 2) Dose-response curves of the antinociceptive activity of meloxicam, piroxicam, paracetamol and nimesulide administered intraperitoneally (i.p.) and intrathecally (i.t.) in the writhing test in mice 

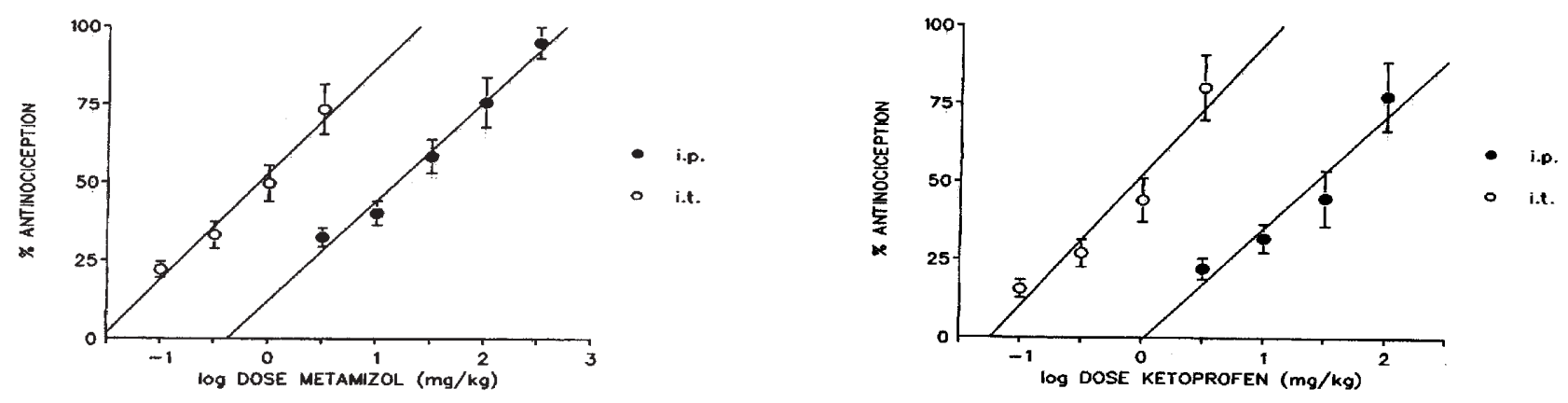

Figure 3) Dose-response curves of the antinociceptive activity of metamizol and ketoprofen administered intraperitoneally (i.p.) and intrathecally (i.t.) in the writhing test in mice

devoid of antinociceptive activity when tested by itself). The following drugs, provided by local laboratories in Chile, were used: ketoprofen (Rhône Poulenc Rorer), piroxicam (Pfizer), diclofenac (Novartis), naproxen (Saval), ibuprofen and clonixine (Pharma Investi of Chile), metamizol (dipyrone, Sanderson), paracetamol (Pasteur), meloxicam (Recalcine) and nimesulide (Schering Plough).

Results were presented as $\mathrm{AD}_{50}$ values with $95 \%$ confidence limits (95\% CL). Parallelism of the lines that were obtained by linear regression analysis of the dose-response curves and relative potencies was calculated according to the method described by Tallarida and Murray (18), and significance was accepted at the 0.05 level.

\section{RESULTS}

Effects of NSAIDs in the writhing test

The intraperitoneal or intrathecal administration of the NSAIDs produced dose-dependent antinociceptive activities in this chemical algesiometric test. The dose-response curves are shown in Figures 1, 2 and 3. The intraperitoneal and intrathecal dose-response curves for each NSAID were statistically parallel. The corresponding $\mathrm{AD}_{50}$ (with $95 \%$ CLs) and the relative intraperitoneal/intrathecal potencies are shown in Table 1. These values vary widely, depending on the route of administration and the algesiometric test that was performed. In the writhing test, $\mathrm{AD}_{50}$ values ranged from 0.85 to $221 \mathrm{mg} / \mathrm{kg}$ after intraperitoneal administration, and ranged from 0.05 to $9.3 \mathrm{mg} / \mathrm{kg}$ after intrathecal administration.

The order of potency, from greatest to least, of the antinociceptive activities that were displayed by NSAIDs (given by intraperitoneal injection) was ibuprofen, meloxicam, diclofenac, nimesulide, piroxicam, clonixine, metamizol, ketoprofen, naproxen and paracetamol. The order of potency, from greatest to least, given by intrathecal injection was ibuprofen, nimesulide, meloxicam, diclofenac, piroxicam, metamizol, ketoprofen, clonixine, naproxen and paracetamol.
TABLE 1

Dose that produced $50 \%$ antinociception $\left(\mathrm{AD}_{50}\right)$ values with $95 \%$ confidence limits (CL) and relative potency of nonsteroidal anti-inflammatory drugs (NSAIDs) administered intraperitoneally (IP) and intrathecally (IT) in the writhing test

\begin{tabular}{|c|c|c|c|}
\hline \multirow[b]{2}{*}{ NSAID } & \multicolumn{2}{|c|}{$\begin{array}{c}\mathrm{AD}_{50} \mathrm{mg} / \mathrm{kg} \\
(95 \% \mathrm{CL})\end{array}$} & \multirow{2}{*}{$\begin{array}{c}\text { Relative } \\
\text { Potency } \\
\text { IT/IP }\end{array}$} \\
\hline & IP & IT & \\
\hline Naproxen & $\begin{array}{c}46.5 \\
(20.7-104.1)\end{array}$ & $\begin{array}{c}6.5 \\
(2.1-21.1)\end{array}$ & 5.04 \\
\hline Clonixine & $\begin{array}{c}11.3 \\
(6.1-21.2)\end{array}$ & $\begin{array}{c}1.1 \\
(0.38-3.1)\end{array}$ & 9.46 \\
\hline Ibuprofen & $\begin{array}{c}0.85 \\
(0.12-6.1)\end{array}$ & $\begin{array}{c}0.05 \\
(0.02-0.13)\end{array}$ & 16.14 \\
\hline Diclofenac & $\begin{array}{c}7.2 \\
(2.6-19.9)\end{array}$ & $\begin{array}{c}0.44 \\
(0.08-2.6)\end{array}$ & 18.08 \\
\hline Meloxicam & $\begin{array}{c}6.5 \\
(3.5-11.8)\end{array}$ & $\begin{array}{c}0.30 \\
(0.07-1.3)\end{array}$ & 20.80 \\
\hline Piroxicam & $\begin{array}{c}9.0 \\
(3.3-24.1)\end{array}$ & $\begin{array}{c}0.51 \\
(0.38-0.69)\end{array}$ & 20.85 \\
\hline Paracetamol & $\begin{array}{c}221.0 \\
(140-346)\end{array}$ & $\begin{array}{c}9.3 \\
(1.9-10.8)\end{array}$ & 21.33 \\
\hline Nimesulide & $\begin{array}{c}7.6 \\
(3.7-15.4)\end{array}$ & $\begin{array}{c}0.27 \\
(0.21-0.39)\end{array}$ & 24.25 \\
\hline Metamizol & $\begin{array}{c}28.5 \\
(19.8-41.1)\end{array}$ & $\begin{array}{c}0.79 \\
(0.4-1.5)\end{array}$ & 24.92 \\
\hline Ketoprofen & $\begin{array}{c}30.3 \\
(11.3-81.6)\end{array}$ & $\begin{array}{c}0.86 \\
(0.28-2.6)\end{array}$ & 30.33 \\
\hline
\end{tabular}

The drugs are listed according to the increment in the relative potency

Effects of NSAIDs in the tail flick test

In the thermal algesiometric tail flick test, the NSAIDs that were administered either intraperitoneally or intrathecally produced dose-dependent antinociceptive activities. The corresponding $\mathrm{AD}_{50}$ values and their $95 \%$ CLs are shown in Table 2. Dose-response curves for intraperitoneal and intrathecal ketoprofen, piroxicam, naproxen, nimesulide, paracetamol and diclofenac were statistically parallel and are shown in Figures 4 and 5. The relative potencies (calcu- 
TABLE 2

Dose that produced $50 \%$ antinociception $\left(\mathrm{AD}_{50}\right)$ values with $95 \%$ confidence limits $(C L)$ and relative potency of nonsteroidal anti-inflammatory drugs (NSAIDs) administered intraperitoneally (IP) and intrathecally (IT) in the tail flick test

\begin{tabular}{|c|c|c|c|}
\hline \multirow[b]{2}{*}{ NSAID } & \multicolumn{2}{|c|}{$\begin{array}{c}\mathrm{AD}_{50} \mathrm{mg} / \mathrm{kg} \\
(95 \% \mathrm{CL})\end{array}$} & \multirow{2}{*}{$\begin{array}{c}\text { Relative } \\
\text { Potency } \\
\text { IT/IP }\end{array}$} \\
\hline & IP & IT & \\
\hline Ketoprofen & $\begin{array}{c}43.7 \\
(12.6-151.6)\end{array}$ & $\begin{array}{c}4.3 \\
(1.6-11.6)\end{array}$ & 8.16 \\
\hline Piroxicam & $\begin{array}{c}160.2 \\
(64.4-398.2)\end{array}$ & $\begin{array}{c}25.5 \\
(1.3-509.4)\end{array}$ & 13.50 \\
\hline Naproxen & $\begin{array}{c}218.1 \\
(58.9-807.7)\end{array}$ & $\begin{array}{c}10.0 \\
(2.7-37.8)\end{array}$ & 17.06 \\
\hline Nimesulide & $\begin{array}{c}28.6 \\
(9.4-86.8)\end{array}$ & $\begin{array}{c}5.0 \\
(3.0-8.3)\end{array}$ & 18.91 \\
\hline Paracetamol & $\begin{array}{c}572.2 \\
(172-1903)\end{array}$ & $\begin{array}{c}28.4 \\
(13-61.8)\end{array}$ & 32.64 \\
\hline Diclofenac & $\begin{array}{c}424.1 \\
(60.5-2972)\end{array}$ & $\begin{array}{c}4.5 \\
(1.4-14.3)\end{array}$ & 33.61 \\
\hline Ibuprofen & $\begin{array}{c}57.3 \\
(21.9-149.6)\end{array}$ & $\begin{array}{c}221.9 \\
(197.5-296.3)\end{array}$ & $\mathrm{N} / \mathrm{A}$ \\
\hline Clonixine & $\begin{array}{c}118.0 \\
(62.8-221.6)\end{array}$ & $\begin{array}{c}8.9 \\
(1.2-64.5)\end{array}$ & $\mathrm{N} / \mathrm{A}$ \\
\hline Meloxicam & $\begin{array}{c}100.4 \\
(42.3-238.5)\end{array}$ & $\begin{array}{c}1.2 \\
(0.6-2.4)\end{array}$ & $\mathrm{N} / \mathrm{A}$ \\
\hline Metamizol & $\begin{array}{c}467.4 \\
(423.1-516.3)\end{array}$ & $\begin{array}{c}179.8 \\
(35.9-900.4)\end{array}$ & $\mathrm{N} / \mathrm{A}$ \\
\hline
\end{tabular}

The drugs are listed according to the increment in the relative potency. NA Not applicable

lated by the intrathecal/intraperitoneal ratio) of the NSAIDs in which dose-response curves were parallel are summarized in Table 2.

The order of potency, from greatest to least, of the antinociceptive activities displayed by NSAIDs that were given by intraperitoneal injection was nimesulide, ketoprofen, ibuprofen, meloxicam, clonixine, piroxicam, naproxen, diclofenac, metamizol and paracetamol. Given by intrathecal injection, the order of potency, from greatest to least, was meloxicam, ketoprofen, diclofenac, nimesulide, clonixine, naproxen, piroxicam, paracetamol, metamizol and ibuprofen.

\section{DISCUSSION}

The results that were obtained in this study confirm that NSAIDs possess different capacities to induce the inhibition of COX, as reflected in their different antinociceptive activities in two nociceptive tests. In the tail flick test, intraperitoneal administration resulted in an $\mathrm{AD}_{50}$ range of 28.6 to $572.2 \mathrm{mg} / \mathrm{kg}$ and intrathecal administration resulted in an $\mathrm{AD}_{50}$ range of 1.18 to $221.9 \mathrm{mg} / \mathrm{kg}$. The dose-response curves for intraperitoneal and intrathecal ibuprofen, clonixine, meloxicam and metamizol, however, significantly deviated from parallelism, which suggested that the antinociceptive activities of these NSAIDs were produced by the activation of different peripheral and spinal pathways (19). In the chemical nociceptive test, ibuprofen was the most potent drug administered either intraperitoneally or intrathecally, while it was clearly less potent in the tail flick test. Ibuprofen has been characterized as a purely competitive inhibitor of COX-1 and COX-2, producing a readily reversible effect (20). On the other hand, naproxen, which was a low potency analgesic in the writhing test, is a more selective COX-2 inhibitor. Naproxen shows a time-dependent effect (involving a second step), which occurs within seconds to minutes and may reflect the induction of a protein conformational change with the formation of a complex in which the inhibitor is bound more tightly to the enzyme (20). Because the tail flick test did not involve an inflammatory component, COX-2 induction should not have been present, and time-dependent inhibitors should conceivably have exhibited lower antinociceptive activities.

In the rat spinal cord/tail in vitro preparation, very low doses of paracetamol (10 to $50 \mu \mathrm{M})$ induced inhibition of COX and blocked bradykinin-activation of nociceptors (21). Even if it is not possible to establish a direct pharmacological correlation with this report (because of the nature of the assays), paracetamol-induced antinociception with algesiometric tests in the present study was evident at doses that were four to 76 times higher than in other studies (6), which strongly suggests the involvement of central neural mechanisms in addition to COX inhibition.

In a study of NSAID suppression of evoked nociceptive activity in individual thalamic neurons, Jurna (22) obtained low $\mathrm{AD}_{50}$ values for diclofenac and ibuprofen; these results support the idea that central effects of NSAIDs contribute to their analgesic efficacy because they do not completely inhibit prostaglandin biosynthesis. The findings on the effects of diclofenac and ibuprofen in the present acetic acid writhing test are comparable with these previous results and with those reported by Bjorkman (6), who demonstrated that diclofenac induced antinociception in visceral pain models (writhing test) but not in somatosensory models (tail flick test).

Reports that ketoprofen is more potent than diclofenac as an analgesic agent in vivo (23) do not agree with the results of the writhing test in the present study. This finding could be explained by differences in experimental models - the route of administration (oral and intravenous compared with intraperitoneal and intrathecal) and the active enantiomers that were used (dexketoprofen compared with racemic ketoprofen).

The two models of animal pain that were used in this study have been used extensively over time. They represent different models of acute pain because the writhing test is a chemical assay that may produce some inflammation and is used as a model of visceral pain, while the tail flick test is a somatic pain model, without inflammation. NSAIDs are less effective $(24,25)$ in the tail flick test than in the writhing test. Our results show that, irrespective of the mechanisms related to the quality and intensity of the pain stimuli, the NSAIDs always elicited antinociception in both tests. 

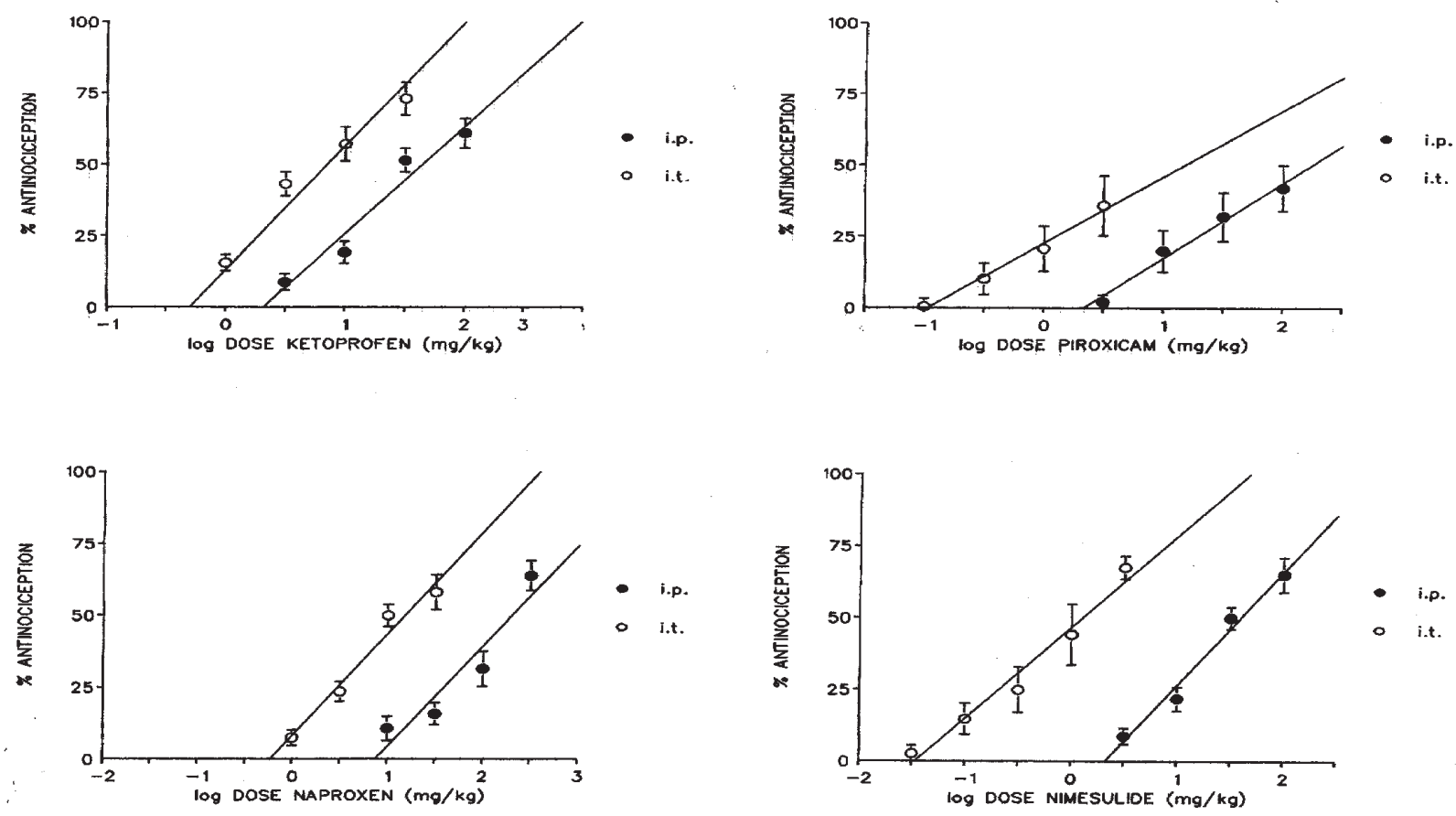

Figure 4) Dose-response curves of the antinociceptive activity of ketoprofen, piroxicam, naproxen and nimesulide administered intraperitoneally (i.p.) and intrathecally (i.t.) in the tail flick test in mice

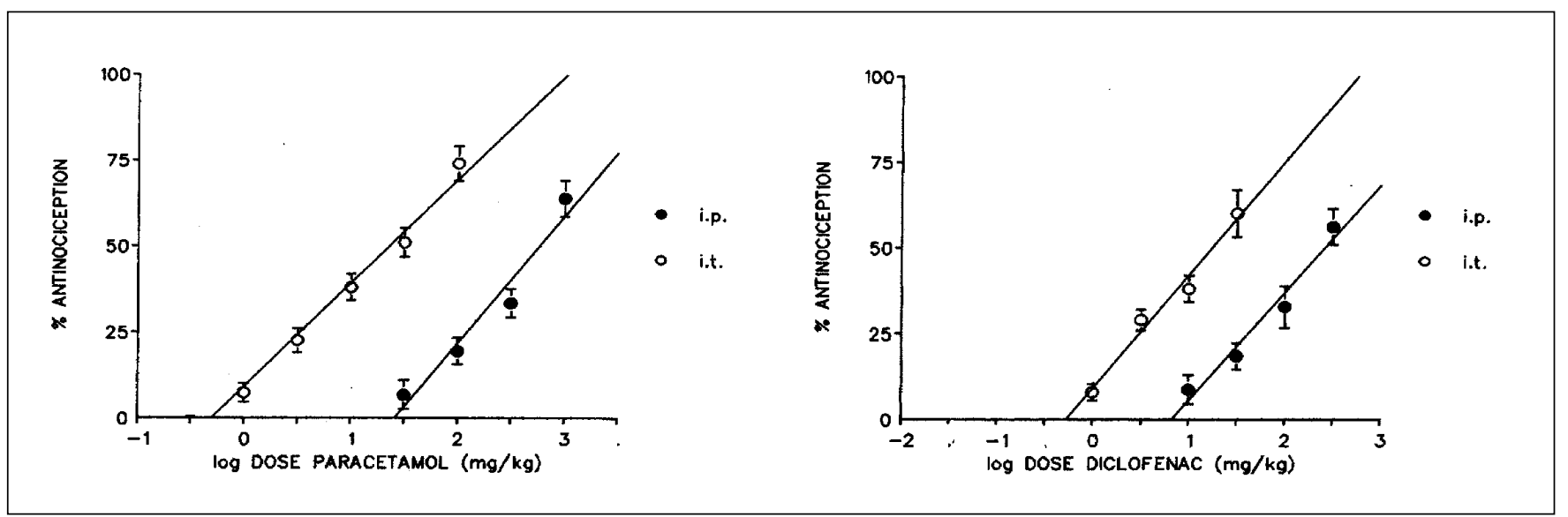

Figure 5) Dose-response curves of the antinociceptive activity of paracetamol and diclofenac administered intraperitoneally (i.p.) and intrathecally (i.t.) in the tail flick test in mice

The results of this study indicate that antinociception after the administration of most NSAIDs might involve central neural mechanisms, which add to the peripheral antinociception that is induced by COX inhibition. These findings demonstrate the increasing importance of the spinal cord in processing and modulating nociceptive input, because intrathecal injections of NSAIDs are always more effective in terms of potency than systemic administration. The antinociceptive efficacy of NSAIDs, therefore, strongly depends on the algesiometric assay that is used and on the type of the nociceptive stimulus to which the test subject is exposed.
ACKNOWLEDGEMENTS: This work was supported by grant number 1990842 from FONDECYT, Chile.

\section{REFERENCES}

1. Walker JS. NSAID: an update on their analgesic effects. Clin Exp Pharmacol Physiol 1995;22:855-60.

2. Hamilton LC, Warner TD. Interactions between inducible isoforms of nitric oxide synthase and cyclo-oxygenase in vivo: investigations using the selective inhibitors, $1400 \mathrm{~W}$ and celecoxib. Br J Pharmacol 1998;125:335-40.

3. Engelhardt G. Pharmacology of meloxicam, a new non-steroidal anti-inflammatory drug with an improved safety profile through preferential inhibition of COX-2. Br J Rheumatol 1996;35(Suppl 1):4-12. 
4. Wolfe MM. Future trends in the development of safer nonsteroidal anti-inflammatory drugs. Am J Med 1998;105:S44-52.

5. Cullen L, Kelly L, Connor SO, Fitzgerald DJ. Selective cyclooxygenase- 2 inhibition by nimesulide in man.

J Pharmacol Exp Ther 1998;287:578-82.

6. Bjorkman R. Central antinociceptive effects of non-steroidal antiinflammatory drugs and paracetamol. Experimental studies in the rat. Acta Anaesthesiol Scand 1995;103:1-44.

7. Bovil JG. Mechanisms of actions of opioids and non-steroidal antiinflammatory drugs. Eur J Anesthesiol 1997;15:9-15.

8. Furst S. Transmitter involved in antinociception in the spinal cord. Brain Res Bull 1999;48:129-41.

9. Papworth J, Colville-Nash P, Alam C, Seed M, Willoughby D. The depletion of substance $\mathrm{P}$ by diclofenac in the mouse. Eur J Pharmacol 1997;325:R1-2.

10. Bjorkman R, Hallman KM, Hedner J, Hedner T, Henning M. Acetaminophen blocks spinal hyperalgesia induced by NMDA and susbtance P. Pain 1994;57:259-64.

11. Granados-Soto V, Flores-Murrieta FJ, Castaneda-Hernández G, López-Muñoz FJ. Evidence for the involvement of nitric oxide in the antinociceptive effect of ketorolac. Eur J Pharmacol 1995;277:281-4.

12. Menzel JE, Kolarz G. Modulation of nitric oxide synthase activity by ibuprofen. Inflammation 1997;21:451-61.

13. Tjolsen A, Lund A, Hole K. Antinociceptive effect of paracetamol in rats is partly dependent on spinal serotonergic systems. Eur J Pharmacol 1991;193:193-201.

14. Walker K, Fox AJ, Urban LA. Animal models for pain research. Mol Med Today 1999;5:319-21.
15. Miranda HF, Sierralta F, Pinardi G. Previous administration of indomethacin or naloxone did not influence ketorolac antinociception in mice. Anesth Analg 1993;77:750-3.

16. Hylden JL, Wilcox GL. Intrathecal morphine in mice: a new technique. Eur J Pharmacol 1980;67:313-6.

17. D'Amour FE, Smith DL. A method for determining loss of pain sensation. J Pharmacol Exp Ther 1941;72:74-9.

18. Tallarida RJ, Murray RB. Manual of Pharmacologic Calculations with Computer Programs. New York: Springer-Verlag, 1986.

19. Goldstein A, Aronov L, Kalman SM. Drug Action: The Basis of Pharmacology, 2nd edn. New York: John Wiley \& Sons, 1974.

20. Marnett LA, Kalgutkar AS. Cyclooxygenase 2 inhibitors: discovery, selectivity and the future. Trends Pharmacol Sci 1999;20:465-9.

21. Dray A, Patel IA, Perkins MN, Rueff A. Bradykinin-induced activation of nociceptors: receptor and mechanistic studies on the neonatal rat spinal cord-tail preparations in vitro. Br J Pharmacol 1992;107:1129-34.

22. Jurna I. Central analgesic effects of non-steroidal anti-rheumatic agents. Z Rheumatol 1991;50:7-13.

23. Cabre F, Fernández MF, Calvo L, Ferrer X, García ML, Mauleón D. Analgesic, antiinflammatory and antipyretic effects of $\mathrm{S}(+)$-ketoprofen in vivo. J Clin Pharmacol 1998;38 (Suppl 12):S3-10.

24. Walker K, Fox AJ, Urban LA. Animal models for pain research. Mol Med Today 1999;5:319-21.

25. Yaksh TL. Spinal systems and pain processing: development of novel analgesic drugs with mechanistically defined models. Trends Pharmacol Sci 1999;20:329-37. 


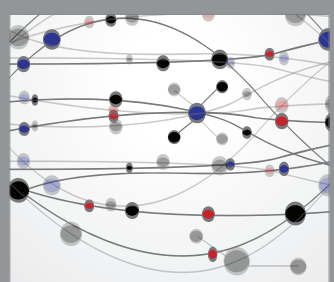

The Scientific World Journal
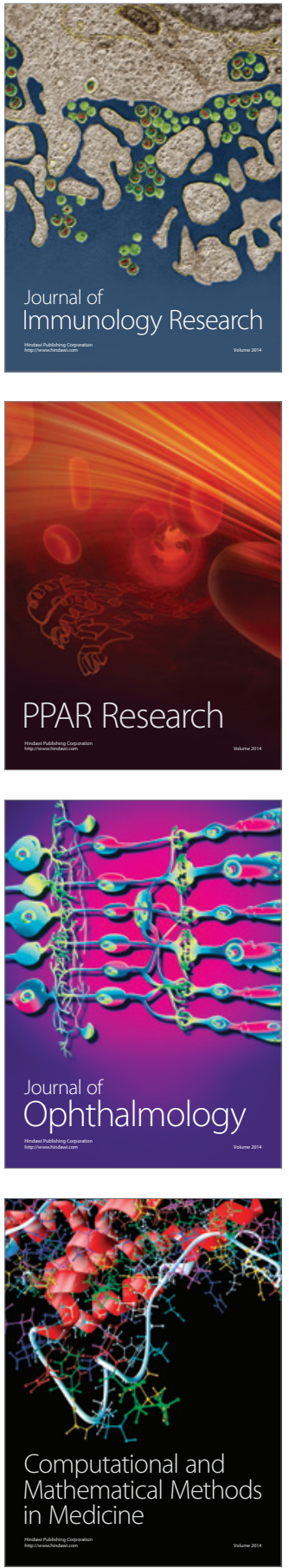

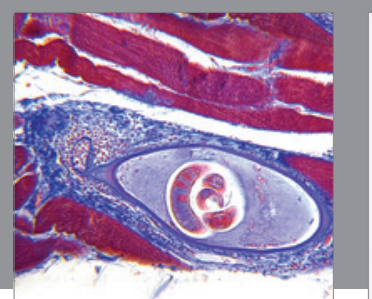

Gastroenterology Research and Practice

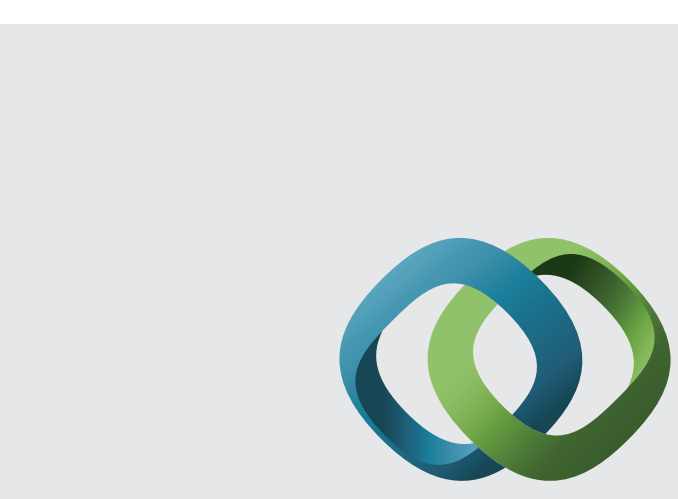

\section{Hindawi}

Submit your manuscripts at

http://www.hindawi.com
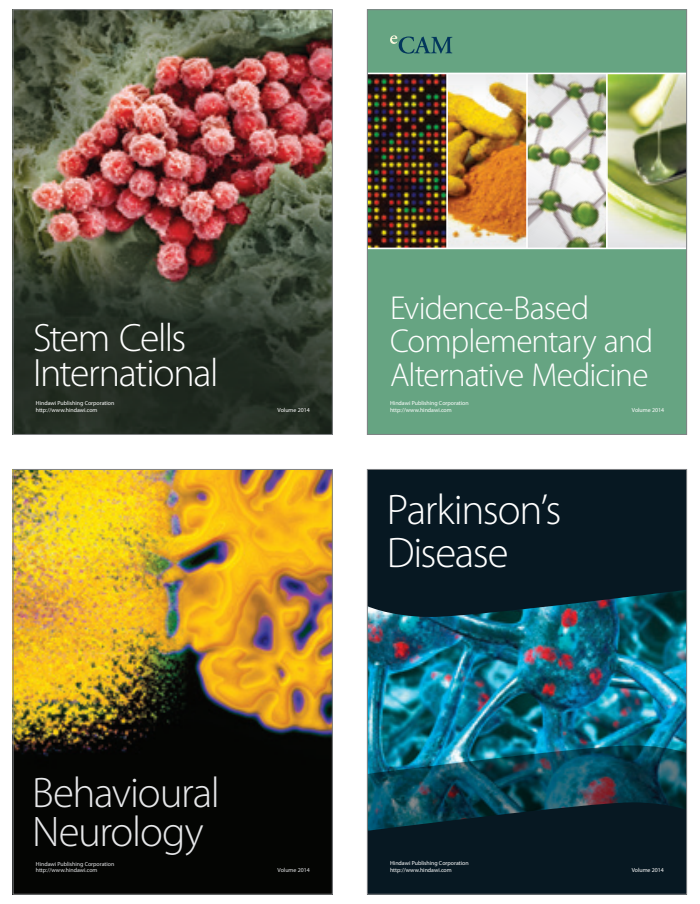
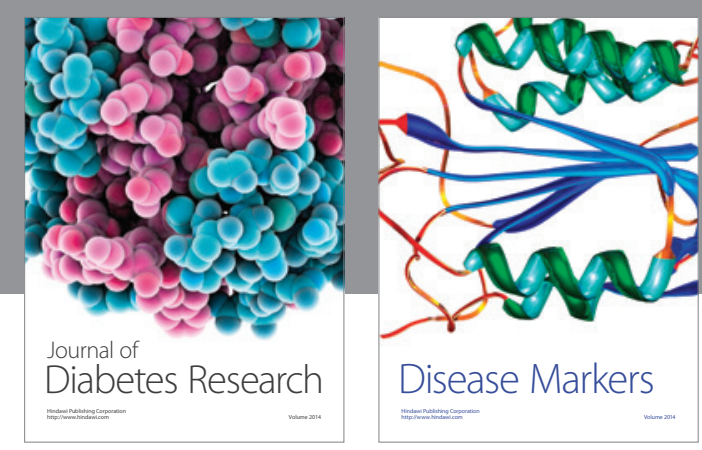

Disease Markers
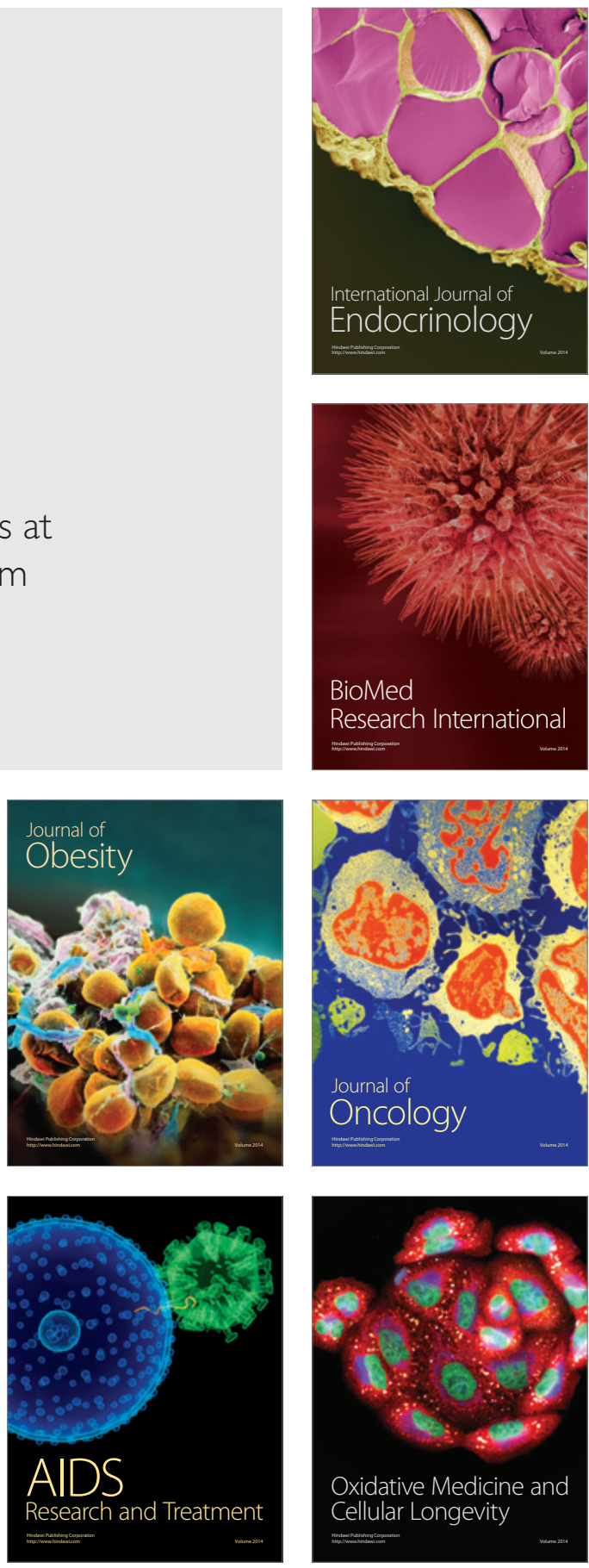